\title{
Advances in crystalline silicon solar cell technology for industrial mass production
}

\author{
Tatsuo Saga* \\ Sharp Corporation, Japan
}

Crystalline silicon photovoltaic (PV) cells are used in the largest quantity of all types of solar cells on the market, representing about $90 \%$ of the world total PV cell production in 2008. Crystalline silicon solar cells are also expected to have a primary role in the future PV market. This article reviews the current technologies used for the production and application of crystalline silicon PV cells. The highest energy conversion efficiency reported so far for research crystalline silicon PV cells is $25 \%$. Standard industrial cells, however, remain limited to $15-18 \%$ with the exception of certain high-efficiency cells capable of efficiencies greater than $20 \%$. High-efficiency research PV cells have advantages in performance but are often unsuitable for low-cost production due to their complex structures and the lengthy manufacturing processes required for fabrication. Various technologies for mono- and polycrystalline PV cells are compared and discussed with respect to the corresponding material technologies, such as silicon ingot and wafer production. High energy conversion efficiency and low processing cost can only be achieved simultaneously through the development of advanced production technologies and equipment, and some of the latest technologies that could lead to efficiencies of greater than $25 \%$ and commercially viable production costs are reviewed.

\begin{abstract}
n 2008, the world annual production of photovoltaic (PV) cells reached more than $7.9 \mathrm{GW}_{\mathrm{p}}\left(\mathrm{W}_{\mathrm{p}}\right.$, peak power under standard test conditions) [1], and the average annual growth rate in PV cell production over the last decade has been more than $40 \%$. Yet the electrical power generated by all PV systems around the world has been estimated to be less than $0.1 \%$ of the total world electricity generation [1]. Nevertheless, the strong growth in PV cell production is expected to continue for many years. Crystalline silicon PV cells, with over 60 years of development, have the longest production history and now account for the largest share of production, comprising up to $90 \%$ of all the solar cells produced in 2008 [1]. Silicon is safe for the environment and one of the most abundant resources on Earth, representing 26\% of crustal material. The abundance and safety of silicon as a resource grants the silicon solar cell a prominent position among all the various kinds of solar cells in the PV industry. World annual PV cell production of $100 \mathrm{GW}_{\mathrm{p}}$ is expected to be achieved by around 2020, and the silicon PV cell is the most viable candidate to meet this demand from the point of view of suitability for large-volume production.

The crystalline silicon PV cell is one of many silicon-based semiconductor devices. The PV cell is essentially a diode with a semiconductor structure (Figure 1), and in the early years of solar cell production, many technologies for crystalline silicon cells were proposed on the basis of silicon semiconductor devices. The synergy of technologies and equipment developed for other silicon-based semiconductor devices, such as large-scale integrated circuits and the many different kinds of silicon semiconductor applications, with those developed for PV cells supported progress in both fields. Process technologies such as photolithography helped to increase energy conversion efficiency in solar cells, and mass-production technologies such as wire-saw slicing of silicon ingots developed for the PV industry were also readily applicable to other silicon-based semiconductor devices. However, the value of a PV cell per unit area is much lower than that
\end{abstract}



Figure 1. Typical mono- and polycrystalline silicon solar cells (upper), and simplified cross-section of a commercial monocrystalline silicon solar cell (lower) (๔ 2010 Sharp).

for other silicon-based semiconductor devices. Production technologies such as silver-paste screen printing and firing for contact formation are therefore needed to lower the cost and increase the volume of production for crystalline silicon solar cells. To achieve parity with existing mains grid electricity prices, known as 'grid parity', lower material and process costs are as important as higher solar cell efficiencies. The realization 


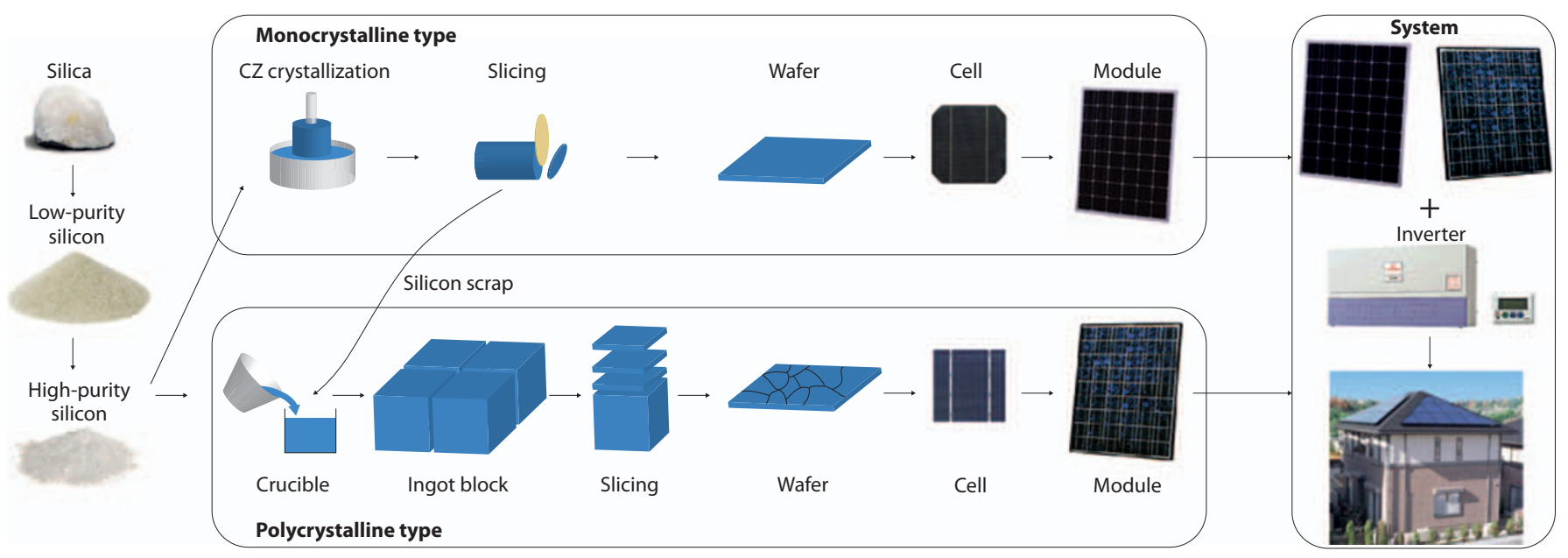

Figure 2. Production process for typical commercial crystalline silicon solar cells (๔ 2010 Sharp)

of high-efficiency solar cells with low process cost is currently the most important technical issue for solar cell manufacturers. Cutting the cost of producing expensive high-purity crystalline silicon substrates is one aspect of reducing the cost of silicon solar cell modules. This review covers the historical and recent technological advances in crystalline silicon solar cells from the perspective of industrial application.

\section{Features of standard crystalline-silicon PV cells and modules}

Crystalline silicon PV cells are the most popular solar cells on the market and also provide the highest energy conversion efficiencies of all commercial solar cells and modules. The structure of typical commercial crystalline-silicon PV cells is shown in Figure 1. Standard cells are produced using one of two different boron-doped p-type silicon substrates; monocrystalline and polycrystalline. The cells of each type are typically $125 \mathrm{~mm}$ (5 inches) or $156 \mathrm{~mm}$ (6 inches) square, respectively. Monocrystalline solar cells are produced from pseudo-square silicon wafer substrates cut from column ingots grown by the Czochralski (CZ) process (see Figure 2). Polycrystalline cells, on the other hand, are made from square silicon substrates cut from polycrystalline ingots grown in quartz crucibles. The front surface of the cell is covered with micrometersized pyramid structures (textured surface) to reduce reflection loss of incident light. An anti-reflection coating (ARC) of silicon nitride $\left(\mathrm{SiN}_{x}\right)$ or titanium oxide $\left(\mathrm{TiO}_{x}\right)$ is overlayed on the textured silicon surface to further reduce reflection loss. Crystalline silicon solar cells have highly phosphorous-doped $\mathrm{n}^{+}$(electron-producing) regions on the front surface of boron-doped p-type (electron-accepting) substrates to form $\mathrm{p}-\mathrm{n}$ junctions. Back-surface $\mathrm{p}^{+}$field (BSF) regions are formed on the back surface of the silicon substrate to suppress recombination of minority carriers (photogenerated electrons). The BSF regions are usually formed by firing screen-printed aluminum paste in a belt furnace. The carriers (electrons) generated in the silicon bulk and diffusion layers are collected by silver contacts (electrodes) formed on the front and back silicon surfaces. The front contact consists of gridlines connected by a busbar to form a combshaped structure. The back contact is usually a series of silver stripes connected to the front bus bar of the adjacent cell via soldered copper interconnects. The contacts are usually formed by firing of screen-printed silver paste at the same time as firing for formation of the BSF regions. The front contact is similarly formed using screen-printed silver paste applied on top of the ARC layer. Contact between the front electrode and the $\mathrm{n}^{+}$region of the silicon substrate is achieved by firing such that the silver penetrates through the ARC layer. The screen-printed front silver contact prepared by firing to penetrate the ARC is one of the most important techniques for large-volume fabrication of modern standard crystalline silicon cells. Other techniques, such as using boron-doped
BSF and nickel-copper plating contacts, are used by a small number of cell manufacturers. The efficiencies of typical commercial crystalline silicon solar cells with standard cell structures are in the range of $16-18 \%$ for monocrystalline substrates and $15-17 \%$ for polycrystalline substrates. The substrate thickness used in most standard crystalline cells is $160-240 \mu \mathrm{m}$. The solar cells are assembled into modules by soldering and laminating to a front glass panel using ethylene vinyl acetate as an encapsulant. The energy conversion efficiency of modules of standard solar cells is roughly $2 \%$ lower than the individual cell efficiency, falling in the range of $12-15 \%$.

The sequence of crystalline silicon solar cell production, from raw materials to modules, is shown in Figure 2. The value chain for crystalline silicon solar cells and modules is longer than that for thin-film solar cells. There are generally three industries related to crystalline silicon solar cell and module production: metallurgical and chemical plants for raw material silicon production, monocrystalline and polycrystalline ingot fabrication and wafer fabrication by multi-wire saw, and solar cell and module production. The cost of PV production is roughly divided in half between solar cell module production and balance-of-system fabrication, which includes the inverter, cables and installation. The fabrication cost for solar cell modules includes the cost of the silicon substrate $(50 \%)$, cell processing (20\%) and module processing (30\%). The cost share is therefore strongly affected by the market price for polysilicon feedstock, and reducing the cost of the silicon substrate remains one of the most important issues in the PV industry.

The industrial goal for PV power is to reduce the electricity generation cost to the equivalent of that for commercial grid electricity. The energy conversion efficiency of solar cells is another important issue because the efficiency influences the entire value-chain cost of the PV system, from material production to system installation. The solar cell efficiency is limited by the three loss mechanisms: photon losses due to surface reflection, silicon bulk transmission and back contact absorption; minority carrier (electrons in the $\mathrm{p}$ region and holes in the $\mathrm{n}$ region) loss due to recombination in the silicon bulk and at the surface; and heating joule loss due to series resistance in the gridlines and busbars, at the interface between the contact and silicon, and in the silicon bulk and diffusion region. In the design of solar cells and processes, these losses are minimized without lowering the productivity of the solar cells.

The electrical performance of a solar cell is determined by the shortcircuit current $\left(I_{\mathrm{sc}}\right)$, open-circuit voltage $\left(V_{\mathrm{oc}}\right)$, current at the maximum power point $\left(I_{\mathrm{mp}}\right)$, voltage at the maximum power point $\left(V_{\mathrm{mp}}\right)$, maximum power $\left(P_{\max }\right)$, fill factor $(\mathrm{FF})$ and energy conversion efficiency $(\eta)$. In research and development, short-circuit current density $\left(J_{\text {sc }}\right)$ is also used. An air mass $1.5\left(\mathrm{AM}_{1.5}\right)$ spectrum condition $\left(1,000 \mathrm{~W} \mathrm{~m}^{-2}\right)$ is the standard test condition for terrestrial solar cells. The $\mathrm{AM}_{1.5}$ condition is defined as 1.5 times the spectral absorbance of Earth's atmosphere; 
in contrast, the spectral absorbance for space is zero (air mass zero, $\mathrm{AM}_{0}$ ). The solar energy under the $\mathrm{AM}_{1.5}$ condition is used as the input energy for calculation of solar cell efficiency. The solar cell fill factor and efficiency are calculated using the following equations.

$$
\begin{aligned}
F F & =\frac{P_{\max }[\mathrm{W}]}{I_{\mathrm{sc}}[\mathrm{A}] \times V_{\mathrm{oc}}[\mathrm{V}]} ;\left(P_{\max }[\mathrm{W}]=I_{\mathrm{mp}}[\mathrm{A}] \times V_{\mathrm{mp}}[\mathrm{V}]\right) \\
\eta[\%] & =\frac{P_{\max }[\mathrm{W}] \times 100}{1,000\left[\mathrm{Wm}^{-2}\right] \times \text { Cell area }\left[\mathrm{m}^{2}\right]}
\end{aligned}
$$

\section{Efficiency improvements}

\section{Historical development}

Bell Laboratory fabricated the first crystalline silicon solar cells in 1953, achieving $4.5 \%$ efficiency, followed in 1954 with devices with $6 \%$ efficiency $[2,3]$. In the ten years since the first demonstration, the efficiency of crystalline silicon cells was improved to around $15 \%$, and were sufficiently efficient to be used as electrical power sources for spacecraft, special terrestrial applications such as lighthouses, and consumer products such as electronic calculators. The improvements in research-cell efficiencies achieved for various kinds of solar cells over the past 30 years are shown in Figure 3. Although crystalline silicon solar cell technologies are not yet as efficient as cells based on single-junction GaAs and multi-junction concentrators, they currently provide a good compromise between efficiency and cost.

The basic cell structure used in current industrial crystalline solar cells, which includes features such as a lightly doped $n^{+}$layer $(0.2-0.3 \mu \mathrm{m})$ for better blue-wavelength response, a BSF formed by a $\mathrm{p} / \mathrm{p}^{+}$low/high junction on the rear side of the cell, a random pyramid-structured lighttrapping surface, and an ARC optimized with respect to the refractive

Table 1. Key technologies for high-efficiency crystalline silicon solar cells

\section{Minimizing photon loss}

Front textured surface of random pyramid or inverted pyramid structures to reduce surface reflection loss

Single- or double-layer ARC to reduce surface reflection loss

Back-contact cell structure to reduce front contact shadow loss

Flat back surface by chemical etching of silicon to improve back reflectivity and reduce photon absorption

Back surface reflector consisted of a dielectric layer and high-reflectivity thin metal layer to reduce photon absorption

Minimizing carrier loss

Passivation of front electrode (partly in contact with highly doped silicon layer) to reduce carrier recombination under front electrode

Shallow-doped $\mathrm{p}-\mathrm{n}$ junction with front surface dielectric passivation layer to reduce carrier recombination in the $\mathrm{n}^{+}$-doped region and at the surface; heterojunction with thin amorphous layers on a crystalline silicon base in a heterojunction cell; front surface field and surface passivation for back contact in a back-junction cell

Locally $\mathrm{p}^{+}$-doped back surface field and point contact structure to reduce carrier recombination in highly doped $\mathrm{p}^{+}$back region

Back surface passivation by a dielectric layer or heterojunction structure to reduce back surface recombination

Minimizing electrical loss

Fine gridline front contact to reduce series resistance of $\mathrm{n}^{+}$-doped region

Selective emitter (deep and highly doped emitter under the contact) to reduce contact resistance of front contact with silicon surface

n-Type or p-type silicon substrates with minority carrier diffusion lengths longer than the base thickness index of the glue used to adhere it, were developed for space and terrestrial use in the 1970s. The efficiency of monocrystalline cells for space use is in the range of $14-16 \%$ under ' 1 sun' $\mathrm{AM}_{0}$ test conditions, equivalent to $15-17 \%$ at $\mathrm{AM}_{1.5}$. These standard structures for crystalline silicon cells are still used in standard industrial crystalline cells, which offer efficiencies in the range of $14-17 \%$.

The key technologies needed to realize efficiencies of higher than $20 \%$ were developed in the 1980 s and ' 90 s, and the latest high-efficiency crystalline silicon cells possess most of these features (Table 1).

\section{Monocrystalline solar cells}

Representative examples of high-efficiency monocrystalline silicon PV cells are the passivated emitter rear localized (PERL) cell, the heterojunction with intrinsic thin layer (HIT) cell, and the back contact, back junction (BC-BJ) cell (Figure 4(a,b,c)). These PV cells feature many of the technologies that provide high efficiency in this type of PV cell. The PERL cell is a research PV cell with front and rear surface passivation layers, an inverted-pyramid light-trapping surface, a rear localized $\mathrm{p}^{+}$layer (BSF), a double-layer ARC and p-type float zone (FZ) monocrystalline silicon substrate. The bulk minority carrier lifetime in PERL cells is longer than $1 \mathrm{~ms}$, and the best output parameters $\left(V_{\mathrm{oc}}, J_{\mathrm{sc}}\right.$, FF and $\eta$ ) achieved for this type of cell are $706 \mathrm{mV}, 42.7 \mathrm{mAcm}^{-2}, 0.828$ and $25.0 \%$ for a $4 \mathrm{~cm}^{2}$ laboratory cell [4]. This cell approaches the limit of current technologies for the absorption of solar photons and the collection of carriers generated in the cell emitter and base. A PERL cell efficiency of $24.7 \%$ was reported almost ten years ago, and the record of $25.0 \%$ reported by researchers from the University of New South Wales (UNSW) in 2009 was obtained after re-measurement of the same cell using newer measurement techniques. The PERL cell has remained the most efficient type of monocrystallinesilicon PV cell for the past ten years [5], and has been the most popular laboratory structure of all the high-efficiency crystalline silicon PV cells. However, the full PERL design is not easy to apply to low-cost industrial production because of the necessity for multiple photolithography steps, similar to semiconductor devices with complex structures. Expensive silicon PV cells for space applications have a similar structure to the PERL cell [6]. The PLUTO cell developed for industrial use by SunTech Power has a simpler passivated emitter solar cell (PESC) design, which was also developed at the UNSW in 1985 [7], and provides efficiency of up to $19.2 \%$ in a $4 \mathrm{~cm}$-square cell [8]. The PESC features front passivation, a selective emitter, and a plated front contact with fine gridlines.

The best output parameters reported for the HIT cell, which was developed for industrial use, are $729 \mathrm{mV}, 39.5 \mathrm{mAcm}^{-2}, 0.800$ and $23.0 \%\left(V_{\mathrm{oc}}, J_{\mathrm{sc}}, \mathrm{FF}\right.$ and $\left.\eta\right)$ for a large $100.4 \mathrm{~cm}^{2}$ cell [9]. This cell has a unique heterojunction structure consisting of very thin, amorphous

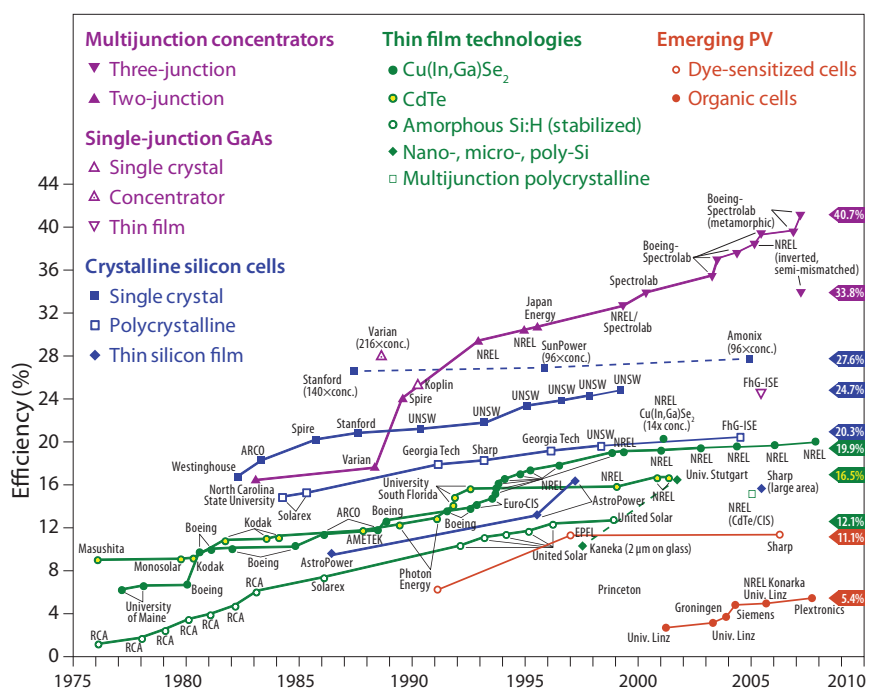

Figure 3. Best research solar cell efficiencies reported by NREL (๔ 2010 NREL) 


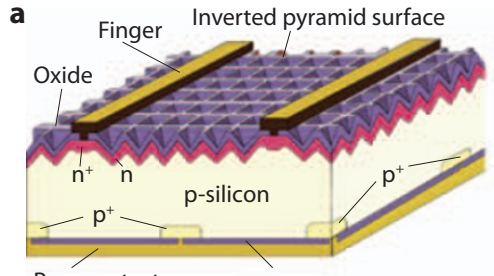

Rear contact
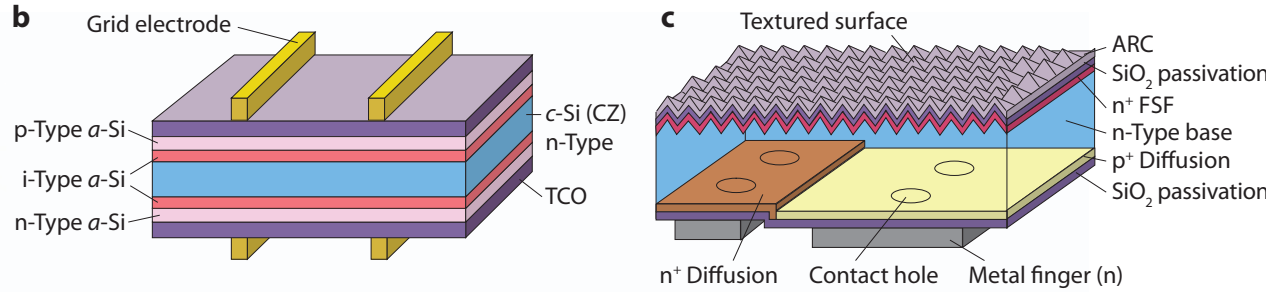

d

Front surface passivation

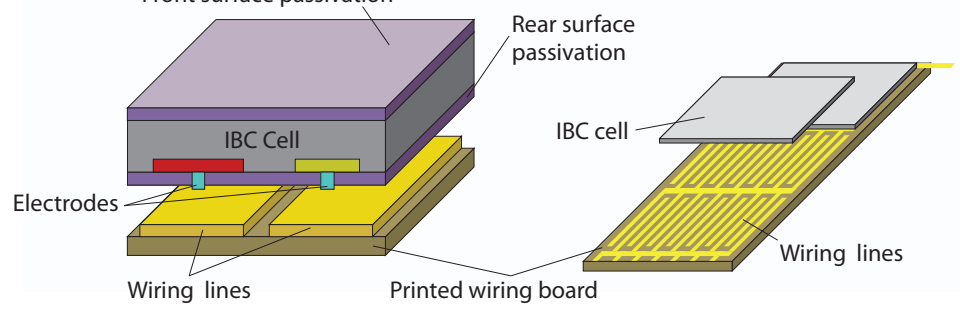

e

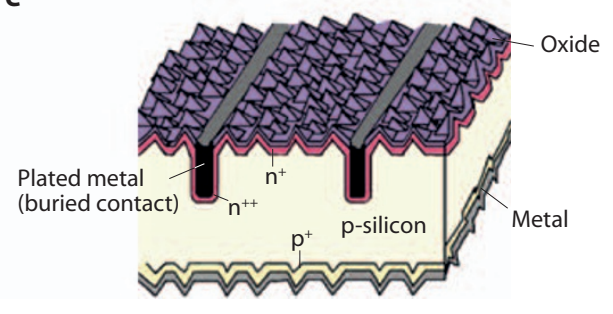

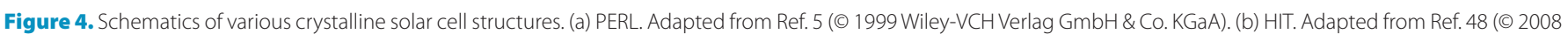

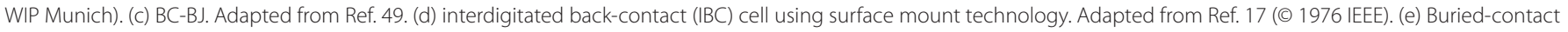
cell structure by BP Solar. Adapted from Ref. 40 (๔ 2008 IEEE). All figures reproduced with permission.

p- and n-doped layers and intrinsic amorphous layers on the front and rear surfaces of a CZ n-type monocrystalline-silicon substrate. This heterojunction structure improves $V_{\text {oc }}$ considerably by the effects of the large energy bandgap of the front amorphous silicon layer and the excellent quality of the interface between the amorphous layer and the crystalline substrate. This cell has the additional advantage of a low temperature coefficient of about $0.30 \% \mathrm{~K}^{-1}$ at $P_{\max }$ compare to about $0.45 \% \mathrm{~K}^{-1}$ for standard industrial crystalline silicon PV cells. This cell has a transparent conductive oxide (TCO) ARC, which reduces the sheet resistivity of the front amorphous layers. The distinctly lower $J_{\mathrm{sc}}$ compared to other high-efficiency PV cells appears to be due to suppressed photocurrent collection by the front amorphous silicon layers and the bulk silicon by the effects of the lower transparency of the TCO layer compared to other ARCs and/or the lower internal quantum efficiency of the amorphous layers. The result is a weaker blue response and lower $J_{\text {sc }}$.

The BC-BJ cell has interdigitated $\mathrm{n}$ - and $\mathrm{p}$-doped regions and $\mathrm{n}$ and $\mathrm{p}$ contacts on the back surface. The original BC-BJ cell, called the front surface field (FSF) cell or interdigitated back contact (IBC) cell, was fabricated and studied for space applications in the late 1970s [10,11]. The BC-BJ-structured point contact (PC) cell developed by Stanford University in the 1980 s gave efficiencies of more than $20 \%$ from the outset [12]. BC-BJ cells were first fabricated for unmanned aircraft and solar race cars by SunPower in the 1990s. The cells were then extended to large-scale production for PV generation systems in the 2000s. The best conversion efficiency reported so far for a large-area industrial BC-BJ cell is $23.4 \%$ [13]. The BC-BJ cell has front and rear surface passivation layers, a random-pyramid light-trapping surface, FSF, interdigitated $\mathrm{n}$ - and $\mathrm{p}$-doped regions on the back surface, $\mathrm{n}$ and $\mathrm{p}$ contact gridlines on $\mathrm{n}$ - and $\mathrm{p}$-doped regions, a single-layer ARC and CZ n-type singlecrystalline silicon substrate with a minority carrier lifetime of longer than $1 \mathrm{~ms}$. Of all the crystalline silicon PV cell modules on the market at this time, only those based on BC-BJ cells provide the possibility of module efficiencies exceeding 20\%. Several laboratories and manufactures are studying methods for improving the design and processing of $\mathrm{BC}-\mathrm{BJ}$ cells $[14,15]$. BC-BJ cells have several advantages compared to the conventional front-contact cell structure: no gridline (sub-electrode) or busbar (main electrode) shading, a front surface with good passivation properties due to the absence of front electrodes, freedom in the design of back contacts (electrodes), and improved appearance with no front electrodes. They also provide advantages in module assembly, allowing the simultaneous interconnection of all cells on a flexible printed circuit (see Figure 4(d)). The low series resistance of interconnection formed by this type of surface-mount technology results in a high FF of 0.800 , compared with around 0.75 for standard silicon PV cell modules $[16,17]$.

\section{Industrial cells}

\section{Monocrystalline solar cells}

p-Type monocrystalline substrates sliced from boron-doped CZ ingots have been used for standard industrial PV cells for many years. In the early era of terrestrial PV cell production, small 2-5-inch-diameter CZ ingots were used, the small size and high cost of which obstructed cost reduction for monocrystalline cells. Much research and development has been devoted to reducing the production costs for $\mathrm{CZ}$ ingots and wafer processing over the past 20 years. CZ wafers with side lengths of 125 and $156 \mathrm{~mm}$, sliced from 6-and 8-inch-diameter ingots, respectively, are now widely used for monocrystalline silicon PV cell fabrication. The fabrication of monocrystalline cells and modules using wafers of the same size as those used for polycrystalline cell production has improved the competitiveness of monocrystalline cells against their polycrystalline counterparts in terms of manufacturing cost per output watt. Monocrystalline cells represented $38 \%$ of all solar cells manufactured in 2008 [1].

There are large differences between the efficiencies of the best research crystalline silicon PV cells and the corresponding industrial cells. The efficiencies of standard industrial monocrystalline PV cells remain in the range of $16-18 \%$, considerably lower than the $25 \%$ efficiency levels of the best research cells. Industrial cells are restricted by economic factors to simple cells that are suitable for high-speed, automated production using low-cost materials. Simple design features, such as front surface texturing and BSF similar, to those developed for terrestrial crystallinesilicon PV cells in the early 1980s are still adopted in most current industrial crystalline cells. To improve cell efficiencies, many cell manufactures are systematically attempting to introduce high-efficiency features, such as finer gridlines, selective emitters or more shallowly doped $\mathrm{n}^{+}$regions, into existing manufacturing processes. The BC-BJ cells and HIT cells have exceptionally high efficiencies for industrial monocrystalline PV cells, but have complex cell structures that require a much longer production process and more specialized equipment compared with the other industrial cells. As a result, it is difficult for these advanced cell types and modules to compete commercially in terms of production cost per output watt. There remains a dilemma in the balance between efficiency improvement and cost reduction for solar cells and modules using existing manufacturing technologies. Innovative and simple manufacturing technologies and equipment for the fabrication of highefficiency solar cells are therefore needed in order to realize significant cost reductions for the production of crystalline silicon PV modules.

Another drawback of the monocrystalline cell technologies is that monocrystalline cells based on p-type CZ silicon substrates are susceptible to light-induced degradation (LID) caused by the recombination 
of reactive boron-oxygen complexes (B s-O 2i). Many studies have been undertaken in attempts to eliminate LID effects in monocrystallinesilicon PV cells, and permanent deactivation of the complex at high temperature $\left(>170^{\circ} \mathrm{C}\right)$ has been reported [18]. Boron-doped magneticfield $\mathrm{CZ}$ wafers and gallium-doped $\mathrm{CZ}$ wafers also show promise for eliminating LID effects in monocrystalline solar cells, and CZ-silicon cells based on phosphorous-doped n-type CZ wafers are also free of LID effects. The high-efficiency PV cells of SunPower and Sanyo are made using n-type CZ-silicon wafers.

\section{Polycrystalline solar cells}

Polycrystalline silicon ingots and wafers were developed as a means of reducing the production costs for silicon ingots, and have been investigated since the mid-1970s [19,20]. Modern polycrystalline furnaces are designed for maximum productivity, casting ingots of around $450 \mathrm{~kg}$. Polycrystalline cells are currently the most widely produced cells, making up about $48 \%$ of world solar cell production in 2008 [1]. Standard polycrystalline industrial cells offer efficiencies of $15-17 \%$, roughly $1 \%$ lower than for monocrystalline cells fabricated on the same production lines. The efficiencies of polycrystalline cell modules, however, are almost the same as those for monocrystalline cells (14\%) due to the higher packing factor of the square polycrystalline cells; monocrystalline cells are fabricated from pseudo-square $\mathrm{CZ}$ wafers and have relatively poor packing factors.

The efficiencies of both monocrystalline and polycrystalline PV cells will be improved in the future through the introduction of high-efficiency structures. The difference in efficiency between monocrystalline and polycrystalline cells is expected to become larger with the introduction of such high-efficiency structures due to the difference in crystal quality (i.e. minority carrier lifetimes). The best of the current research polycrystalline silicon cells, a PERL cell developed by Fraunhofer ISE [21], provides an energy conversion efficiency of $20.3 \%$. This PERL cell has a laser-fired contact back structure that gives a $V_{\text {oc }}$ of as high as $664 \mathrm{mV}$. The efficiency of this polycrystalline cell, however, remains about $5 \%$ lower than that for the best of the research monocrystalline PERL cells, attributable mainly to the quality difference between mono- and polycrystalline substrates. Polycrystalline substrates are subject to higher rates of minority carrier recombination, both at active grain boundaries and within crystalline grains due to high dislocation and impurity densities in comparison with FZ or CZ monocrystalline substrates. A considerable amount of research and development has been conducted on improving the efficiencies of polycrystalline solar cells over many years, by both public and industrial

Table 2. Key technologies for high-efficiency polycrystalline silicon solar cells

Minimizing photon loss

Front textured surface by acid etching (including honeycomb texturing) or reactive ion etching

Chemical polishing (etching) of back surface

Back surface reflector consisting of a dielectric layer and highly reflective thin metal layer

Minimizing carrier loss

Shallowly doped $\mathrm{n}^{+}$regions with $\mathrm{SiN}_{\mathrm{x}}$ surface passivation layer

p-Type silicon substrates with minority carrier diffusion length longer than base thickness

Local BSF and point contacts, such as the laser fired contacts

Back surface passivation with $\mathrm{SiO}_{2}$ and/or $\mathrm{SiN}_{x}$ layers

Minimizing electrical loss

Fine gridlines for front electrode by advanced screen printing techniques, such as stencil printing [46]

Selective emitter (deep, highly doped emitter beneath front electrodes)

Deposition of seed layers then copper plating for metallization instead of screen-printed silver paste laboratories, and recent high-efficiency polycrystalline silicon solar cells now have the features listed in Table 2 . These features are generally the same as for recent monocrystalline solar cells.

The honeycomb-structured polycrystalline solar cells demonstrated recently by Mitsubishi Electric exhibit efficiencies of over $19.3 \%$ and come in large $15 \mathrm{~cm} \times 15 \mathrm{~cm}$ cells [22]. These polycrystalline cells have a distinct front honeycomb-textured surface to reduce light reflection, and the introduction of this front textured surface has resulted in a high $J_{\text {sc }}$ of $37.5 \mathrm{~mA} \mathrm{~cm}^{-2}$ for cells with screen-printed and fired silver-paste electrodes. This cell also has the PERL structures of front surface passivation, rear surface passivation with local BSF, and a selective emitter for improved cell efficiency.

Approaches to reduce cell costs also include using thinner silicon wafers. High-efficiency (18.1\%) polycrystalline silicon cells fabricated using $100 \mu \mathrm{m}$-thick wafers were reported by Sharp in 2009 [23]. The electrical performance of crystalline silicon PV cells with the standard back surface structure of an aluminum-alloyed BSF decreases as the substrate becomes thinner. High-efficiency polycrystalline cells with an $\mathrm{SiN}_{x}$ passivation layer and thin aluminum reflector on the back silicon surface display less of a performance degradation with decreasing substrate thickness for substrates of $100-180 \mu \mathrm{m}$ in thickness. Cells with rear passivation and local BSF on $100 \mu \mathrm{m}$-thick substrates provide the additional advantage of less cell bowing compared with the standard aluminum alloyed BSF cells on substrates of the same thickness.

New types of back-contact polycrystalline cells, such as metal wrap through (MWT) cells and emitter wrap through (EWT) cells (Figure 5), have also been developed by institutes and companies such as ECN, Kyocera and Advent Solar [24-26]. BC-BJ cells without a front p-n junction require high-quality monocrystalline substrates with high minority carrier lifetimes. The WT back-contact cells, however, are suitable for use with polycrystalline substrate having relatively short minority carrier lifetimes (related to cell thickness). The front $\mathrm{p}-\mathrm{n}$ junctions in these cells can collect most carriers generated in the region from the front n-doped layer to the back substrate surface. These back-contact cells have laser-drilled through-holes that can wrap through front n-electrodes and/or n-doped regions to the back surfaces. The MWT cells require only a relatively small number of through-holes to direct photogenerated electrons to the back surface through the metal electrodes and n-doped emitters, and produce higher collection photocurrents due to absence of a bus bar (main electrode) on the front surface as in conventional cells. A high $J_{\text {sc }}$ of $37.3 \mathrm{mAcm}^{-2}$ and an efficiency of $18.3 \%$ were reported for a recent MWT cell by Kyocera [26], and the module efficiency for MWT cell modules by ECN, 16.4\%, is the highest reported to date [25].

The EWT cells have a larger number of close-spaced through-holes, which direct photogenerated electrons to the back surface solely through n-doped emitters. The EWT cells produce even higher photocurrents by eliminating the both busbar (main electrode) and gridline (sub-electrode) shading on the front surface. A high $J_{\mathrm{sc}}$ of $37.5 \mathrm{mAcm}^{-2}$ and efficiency of $17.1 \%$ were reported recently for EWT cells by Q-Cells. The target for industrial polycrystalline PV cells is to realize average cell efficiencies of $17 \%$ in large-scale production [24].

Many methods have been investigated to improve the quality of

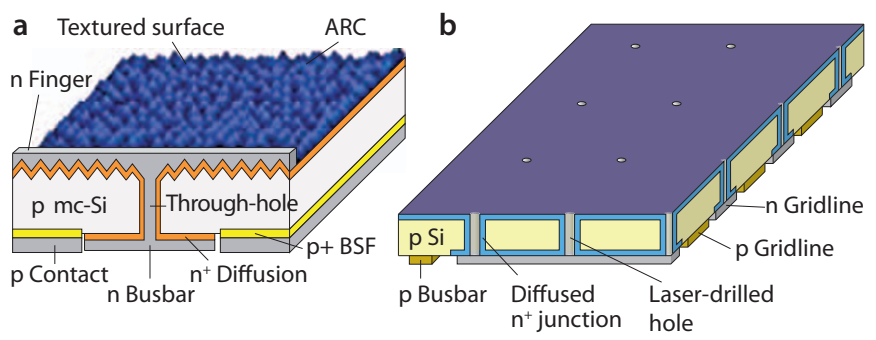

Figure 5. Schematics of back-contact solar cell structures. (a) MWT. Adapted from Ref. 26 (๔ 2008 WIP Munich). (b) EWT. Adapted from Ref. 25 (๔ 2008 IEEE). All figures reproduced with permission. 


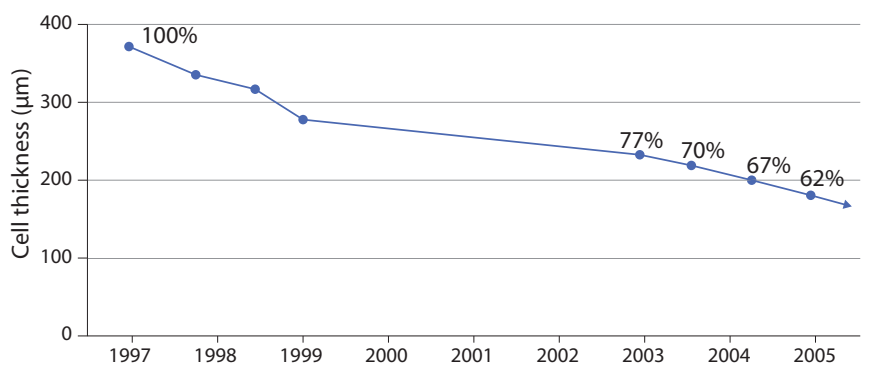

Figure 6. Reduction of silicon wafer thickness by Sharp (๔ 2010 Sharp)

polycrystalline substrates to match that of the more expensive $\mathrm{CZ}$ monocrystalline wafers. The dendritic casting method is one such approach that allows the grain orientation and size to be controlled, resulting in high-quality dendritic crystals with parallel twinning. Solar cells based on dendritic polycrystalline wafers show efficiencies of as high as $17 \%$, comparable to the efficiencies provided by CZ monocrystalline cells using the same cell fabrication process [27].

\section{Materials and processing}

The raw, high-purity polysilicon material used for the fabrication of crystalline silicon solar cells is generally made by the Siemens method. The market price for raw silicon is affected by the demand-supply balance for solar cell and semiconductor fabrication, and can fluctuate markedly. In 2006-2008, for example, the cost of raw silicon as a proportion of total solar cell module cost jumped from $20-30 \%$ to more than $50 \%$ due to a market shortage of silicon. Reducing the cost of silicon in a cell module by reducing the substrate thickness is therefore an important aspect of achieving overall cost reductions for solar cell modules. Wire-saw wafer slicing is one of the key production technologies for industrial crystalline silicon PV cells, and improvements in wafer slicing technology have resulted in a reduction in raw wafer thickness from $370 \mu \mathrm{m}$ to $180 \mu \mathrm{m}$ since 1997 for Sharp industrial polycrystalline-silicon cells (Figure 6). To introduce wafers thinner than $150 \mu \mathrm{m}$, sophisticated manufacturing processes suitable for ultrathin wafers will be needed, and the processes will need to provide high processing speed and high manufacturing yield in each of the process steps of wafer slicing, cell fabrication and module assembly.

Several alternative growth methods have been proposed over the past four decades for the production of polycrystalline substrates directly from molten silicon, including edge-defined film-fed growth (EFG), string ribbon growth (SRG), and ribbon growth on substrate (RGS) [28-30]. These methods potentially make it possible to reduce the amount of silicon used in PV cell fabrication. The EFG and SRG methods are used on industrial production scales by SCHOTT Solar and Evergreen Solar, respectively [31]. These two methods have the advantages of low silicon consumption per $\mathrm{W}_{\mathrm{p}}$ and high cell efficiencies in comparison with the RGS method. These methods afford inexpensive but slightly wavey polycrystalline substrates in comparison with the standard polycrystalline substrates. Recently manufactured cells based on direct-grown substrates have almost the same efficiencies as those of standard cast-silicon polycrystalline cells. However, the smaller EFG- and SRG-based cells, which are roughly half the size of standard industrial cells, incur higher cell and module processing costs. A crystallization on dipped substrate method, which can be used to produce standard-sized wafers $(156 \mathrm{~mm} \times 156 \mathrm{~mm})$ directly from molten silicon in a crucible, was recently proposed by Sharp [32].

The front emitter layer of crystalline silicon PV cells is formed by phosphorus diffusion techniques in a quartz tube or belt furnace. Solid $\mathrm{P}_{2} \mathrm{O}_{5}$ or liquid $\mathrm{POCl}_{3}$ is used as the phosphorus diffusion source. Phosphorous diffusion techniques the exploit gettering effects to reduce impurity densities in a silicon wafer and thereby improve minority carrier lifetime have been demonstrated to be effective provided diffusion is conducted under phosphorus supersaturation conditions (doping level above the solid solubility in silicon) [33-35].
The BSF layers in industrial cells are formed by alloying of screen-printed aluminum paste in a belt furnace. This process provides high productivity and relatively low process cost for BSF formation. Aluminum-paste alloying has the additional advantage of inducing wafer gettering effects in both polycrystalline and monocrystalline silicon PV cells similar to the phosphorus diffusion technologies [36,37]. Metal impurities, such as iron or copper, can be eliminated from bulk silicon by aluminum gettering effects, which can improve the minority carrier diffusion length.

The screen printing and firing of silver paste to make contact with the bulk silicon surface by penetrating the ARC is a well-established, simple and fast process for forming front and rear electrodes. It is also the most widely used and lowest-cost method for forming electrodes in industrial crystalline silicon PV cells. The front gridlines are designed so as to optimize the trade-off between shadow loss and series resistance. As an alternative to the screen-printed silver paste approach, plated electrodes of layered nickel, copper and silver have been developed by researchers at the UNSW for use in buried-contact (BC) cells $[38,39]$. The BC cell fabricated by BP Solar is shown in Figure 4(e) [40]. Crystalline silicon PV cells with plated electrodes have excellent electrical characteristics due to their low series resistance and fine gridlines, which result in a much smaller shadow area. However, plated electrodes, which are formed by a wet process, have not yet become as widely used as the screen-printed silver paste electrodes. The silver used as the electrode material in crystalline silicon cells will become a critical material resource when crystalline silicon solar cell production reaches the large volumes predicted in the future. Copper and aluminum have therefore been considered as substitutes for silver in silicon PV contacts.

\section{Future views on crystalline silicon solar cells}

Industrial solar cells module must reach a price level of $\$ 1 / \mathrm{W}_{\mathrm{p}}$ with a total system price level of $\$ 2 / \mathrm{W}_{\mathrm{p}}$ to reach grid parity, and to become competitive with coal or nuclear power generation will need to be mass produced at a total system cost of less than $\$ 1 / \mathrm{W}_{\mathrm{p}}$. Achieving even a module price of $\$ 1 / \mathrm{W}_{\mathrm{p}}$ will require modules to be produced at a cost of less than $0.7 \$ / \mathrm{W}_{\mathrm{p}}$. Although such low costs remain very challenging for modules based on crystalline silicon solar cells, cost reductions to such a level are considered to be possible based on the technologies presented in this review, and the cost reduction must be accomplished while public incentives for PV systems remain in effect. The annual production volume for all kinds of solar cells is expected to exceed $100 \mathrm{GW}_{\mathrm{p}} /$ year by around 2020. Crystalline silicon cell modules have a long history of proven field operation and offer high efficiencies while presenting fewer resource issues than many competing technologies. As such, crystalline silicon PV cells are expected to be strongly represented in the future solar cell market.

To reach these future price levels, new technologies as listed in Table 3 will be needed for crystalline silicon solar cells and modules. New technologies to break through the efficiency barrier of $25 \%$ for

Table 3. New technologies for high-efficiency crystalline silicon solar cells and modules

Novel technologies to break through efficiency barrier of $25 \%$

Wafer slicing technologies and equipment for ultrathin $(50 \mu \mathrm{m})$ wafers

Direct slicing technologies and equipment for ultrathin wafers without kerf loss [47]

Production technologies and equipment for solar cells and modules based on ultrathin wafers

High-quality polycrystalline ingot technologies providing performance comparable to monocrystalline cells

Low-cost contact-forming technologies and materials to replace screenprinted and fired silver paste

Low concentration (around 10x) and high efficiency module technologies to minimize total PV system cost 
crystalline silicon PV cells are being studied by many researchers and institutes around the world, but there have yet to be any practical improvements in cell efficiency. The peak theoretical efficiency in a crystalline silicon solar cell based on a single homojunction and a bulk silicon energy bandgap of $1.1 \mathrm{eV}$ is $30 \%$ under 1 sun $\mathrm{AM}_{1.5}$ illumination. To break through this ideal efficiency limit based on existing Schockley and Queisser solar cell theory, novel technologies based on quantum dot (QD) and quantum well structures have been proposed and studied by many researchers. Multi-junction designs have been attempted in many forms for improving solar cell efficiency beyond that of a single-junction cell. For example, a triple-junction solar cell with a silicon bottom cell is expected to give efficiencies of more than $40 \%$. Researchers at the UNSW have also proposed a silicon-based tandem junction solar cell incorporating silicon QD technology [41]. An effective bandgap of up to $1.7 \mathrm{eV}$ has been demonstrated for $2 \mathrm{~nm}$ diameter silicon QDs embedded in $\mathrm{SiO}_{2}$ [42]. Photon management, such as up- and down-conversion and plasmonic effects, are other potential approaches that could add extra efficiency based on existing high-efficiency silicon cells [43-45]. These technologies aim at shifting the photon energy of sunlight to match the sensitivity of the solar cell by adding special optical features (e.g. a fluorescent coating layer including rare-earth elements for up-and down-conversion) to the front and/or rear surface of the cells without modifying the structure of the solar cell itself.

These high-efficiency technologies, however, generally incur higher production costs compared to standard silicon cells. Cell and module manufacturing technologies that satisfy both high efficiency and low cost will be essential for industrial production in the near future. The impacts of novel technologies such as QDs and photon management will be interesting to watch as research and development on crystalline silicon solar cells continues.

\section{References}

[1] Photon International, 176 (March 2009).

[2] G. L. Pearson, 18th IEEE Photovoltaic Specialists Conference, PV founders award luncheon (1985).

[3] D. M. Chapin, C. S. Fuller, G. L. Pearson, J. Appl. Phys. 25, 676 (1954).

[4] M. A. Green, Prog. Photovoltaics 17, 183 (2009).

[5] J. Zhao, A. Wang, M. A. Green, Prog. Photovoltaics 7, 471 (1999).

[6] H. Washio et al., Proc. 23rd IEEE Photovoltaic Specialists Conference, 1347 (1993).

[7] M. A. Green, A. W. Blakers, S. R. Wenham, S. Narayanan, Proc. 18th IEEE Photovoltaic Specialists Conference, 39 (1985).

[8] Z. Shi, S. Wenham, J. Ji, Proc. 24th European Photovoltaic Solar Energy Conference, 1090 (2009).

[9] M. Taguchi et al., Proc. 24th European Photovoltaic Solar Energy Conference, 1690 (2009).

[10] O. V. Roos, B. Anspaugh, Proc. 13th IEEE Photovoltaic Specialists Conference, 1119 (1978).

[11] L. J. Cheng, D. C. Leung, Proc. 14th IEEE Photovoltaic Specialists Conference, $72(1980)$

[12] R. A. Sinton, Y. Kwark, P. Gruenbaum, R. M. Swanson, Proc. 18th IEEE Photovoltaic Specialists Conference, 61 (1985).

[13] R. M. Swanson, 33rd IEEE Photovoltaic Specialists Conference, keynote session (2008).
[14] S. Kluska, F. Granek, M. Hermle, S. W. Glunz, Proc. 23rd European Photovoltaic Solar Energy Conference, 1590 (2008).

[15] K. A. Münzer, M. G. Winstel, A. Krause, R. E. Schlosser, Proc. 23rd European Photovoltaic Solar Energy Conference, 1875 (2008).

[16] J. H. Bultman et al., Proc. 3rd World Conference on Photovoltaic Energy Conversion, 979 (2003).

[17] K. Nakamura et al., Proc. 23rd European Photovoltaic Solar Energy Conference, 1006 (2008).

[18] B. Lim, S. Hermann, K. Bothe, J. Schmidt, R. Brendel, Proc. 23rd European Photovoltaic Solar Energy Conference, 1018 (2008).

[19] J. Lindmayer, Proc. 12th IEEE Photovoltaic Specialists Conference, 82 (1976).

[20] H. Fischer, W. Pschunder, Proc. 12th IEEE Photovoltaic Specialists Conference, 86 (1976).

[21] O. Schultz, S. W. Glunz, G. P. Willeke, Prog. Photovoltaics 12, 553 (2004).

[22] S. Hamamoto et al., Proc. 24th European Photovoltaic Solar Energy Conference, 1410 (2009).

[23] S. Ooka et al., Proc. 19th International Photovoltaic Science and Engineering Conference, CSI8-O-4 (2009).

[24] A. A. Mewe et al., Proc. 24th European Photovoltaic Solar Energy Conference, 946 (2009).

[25] J. M. Gee, P. Hacke, M. Hilali, J. C. Jiméno, Proc. 33rd IEEE Photovoltaic Specialists Conference, 1 (2008)

[26] S. Inoue et al., Proc. 23rd European Photovoltaic Solar Energy Conference, 988 (2008).

[27] K. Nakajima, K. Fujiwara, N. Usami, S. Okamoto, 2008 IUMRS-ICEM Photovoltaics Symposium (2008).

[28] K. V. Ravi, J. Cryst. Growth 39, 1 (1977).

[29] E. Sachs, Proc. Flat-Plate Solar Array Project Research Forum on the High-Speed Growth and Characterization of Crystals for Solar Cells, 279 (1984).

[30] H. Lange, I. Schwirtlich, J. Cryst. Growth 104, 108 (1990).

[31] S. Seren et al., Proc. 4th World Conference on Photovoltaic Energy Conversion, 972 (2006).

[32] T. Takakura et al., Proc. 23rd European Photovoltaic Solar Energy Conference, 1472 (2008).

[33] S. A. McHugo, H. Hieslmair, E. R. Weber, Appl. Phys. A 64, 127 (1997).

[34] S. Wenham, M. Green, Photovolt. 4, 3 (1996).

[35] W. Schröter, R. Kühnapfel, Appl. Phys. Lett. 56, 2207 (1990).

[36] G. C. Cheek, R. P. Mertens, R. van Overstraeten, L. Frisson, IEEE Trans. Electron Dev. 31, 602 (1984).

[37] P. Lolgen et al., Proc. 23rd IEEE Photovoltaic Specialists Conference, 236 (1993).

[38] S. R. Wenham, M. A. Green, US Patent 4,726,850 (1988).

[39] S. R. Wenham, M. A. Green, US Patent 4,748,130 (1988).

[40] M. A. Green et al., Proc. 20th IEEE Photovoltaic Specialists Conference, 411 (1988).

[41] M.A. Green et al., Proc. 23rd European Photovoltaic Solar Energy Conference, 1 (2008)

[42] S. Park, E. Cho, X. Hao, G. Conibeer, M. A. Green, Proc. 23rd European Photovoltaic Solar Energy Conference, 189 (2008).

[43] S. Schweizer, P. Miclea, B. Henke, B. Ahrens, Proc. 23rd European Photovoltaic Solar Energy Conference, 54 (2008).

[44] H. Mataki et al., Proc. 34th IEEE Photovoltaic Specialists Conference, 600 (2009).

[45] D. M. Schaadt, B. Feng, E. T. Yu, Appl. Phys. Lett. 86, 063106 (2005).

[46] J. Hoornstra, B. Heurtault, Proc. 24th European Photovoltaic Solar Energy Conference, 989 (2009).

[47] F. Henley et al., Proc. 24th European Photovoltaic Solar Energy Conference, 886 (2009).

[48] H. Kanno et al., Proc. 23rd European Photovoltaic Solar Energy Conference, 1136 (2008).

[49] K. McIntosh, M. Cudzinovic, D. Smith, W Mulligan, R. Swanson., Proc. 3rd World Conference on Photovoltaic Energy Conversion, 4O-D10-05 (2003).

\section{Author profile}

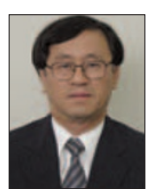

\section{Tatsuo Saga}

Tatsuo Saga received his BS and MS degrees from the Faculty of Engineering, Nagoya University. He joined Sharp Corporation in 1974, where he worked on the development of photovoltaic cells for space use. Since 1999, he has been general manager of the engineering and production departments for terrestrial- and space-use

photovoltaic cells and modules. He became division deputy general manager of the Solar Systems Division in Solar Systems Group in 2003, and group deputy general manager of the Solar Systems Group in 2006 and the Solar Systems Development Group in 2009. He is currently an executive technical research fellow in Sharp's Solar System Development Group. 